\title{
Cranial MRI findings in a case with Seckel syndrome
}

\section{Seckel sendromlu bir olguda kraniyal MRG bulguları}

\author{
Mehmet Haydar Atalar
}

Department of Radiology, Cumhuriyet University Faculty of Medicine, Sivas, Turkey,

Corresponding author: Mehmet Haydar Atalar, MD., Department of Radiology, Cumhuriyet University Faculty of Medicine, Sivas, Turkey

E-mail: mhatalar@gmail.com

Received/Accepted: April 22, 2018 / July 10, 2018

Conflict of interest: There is not a conflict of interest.

\section{SUMMARY}

Seckel's syndrome (SS) is a rare, heterogeneous form of primordial dwarfism. The presence of mental retardation and neurologic signs is one of the peculiar features of this syndrome. We herein present the cranial MR findings in a child patient with Seckel's syndrome.

Keywords: Brain,Dwarfism,Magnetic resonance imaging,Seckel syndrome

\section{ÖZET}

Seckel sendromu (SS) nadir, heterojen bir primordiyal cücelik türüdür. Zeka geriliği ve nörolojik belirtilerin varlığı bu sendromun kendine has özelliklerinden biridir. Biz burada Seckel sendromlu bir çocuk hastada kraniyal MR bulgularını sunuyoruz.

Anahtar sözcükler: Beyin, Cücelik, Manyetik rezonans görüntüleme, Seckel sendromu

\section{INTRODUCTION}

Seckel syndrome (SS) is a rare cause of primordial autosomal recessive dwarfism. It was first defined by Seckel in 1960. This rare condition is characterized by low birth weight, short but proportional stature, microcephaly, mental retardation, and facial anomalies ${ }^{1}$. Hematological, renal, cardiac, and central nervous system anomalies may also accompany the clinical picture ${ }^{1,2}$. In this report, we discussed the co-existing magnetic resonance imaging (MRI) findings in the light of the available literature data in a rare case of SS.

\section{CASE REPORT}

A 14-year-old male patient with SS referred for a preliminary diagnosis of mental retardation was examined with cranial radiography and cranial MRI. The patient's prenatal and postnatal history were not revealing. There was a second-degree consanguineous marriage between the parents. The patient had a height of $137 \mathrm{~cm}$ and a head circumference of $51 \mathrm{~cm}$. The bulges of the cranial sutures could be palpated. Additionally, he had a receding forehead, prominent eyes with a normal interocular distance, a prominent, beak-like nose, retrognathia, and low-set ears. He had a highlyarched, intact palate. He had mental retardation. He had deformed teeth and a maloccluded chin. The examination of other systems was normal. $\mathrm{He}$ 
also had normal laboratory tests and a normal chromosome analysis.

There was no solid organ pathology on abdominal ultrasonography. Direct films were obtained to define skeletal system findings. Cranial roentgenograms revealed microcephalia, beak-like nose, retrognathia, frontal bone hypoplasia, and prominent convolutional signs. A cranial MRI to detect potential concurrent central nervous system
(CNS) abnormalities showed a prominent, beaklike nose and a hypoplastic mandible. Posterior fossa structures were normal. Corpus callosum was hypoplastic. The posterior horns of the lateral ventricles were minimally dilated but the outer subarachnoid spaces and white matter appeared normal. There was a lissencephalic appearance in both cerebral hemispheres, particularly in the frontotemporal regions (Figure 1a-c).

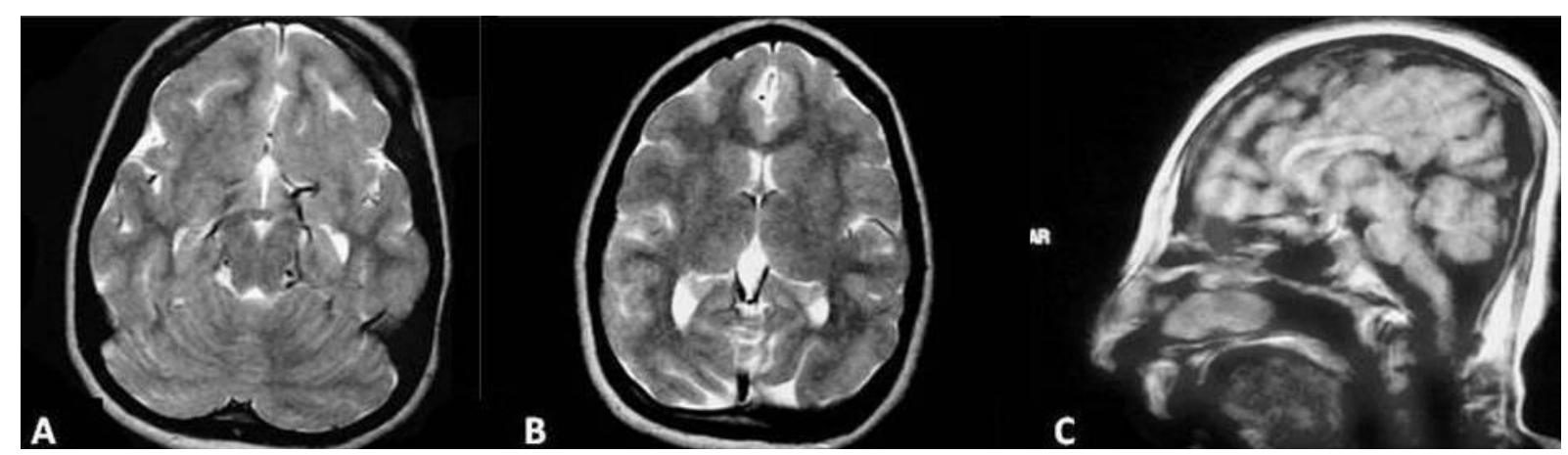

Figure 1. (A, B) Axial T2 weighted MR sections show lissencephaly in both frontotemporal regions and mild dilatation of the posterior horns of the lateral ventricle. (C) The sagittal T2 weighted MRI section shows a prominent beak-like nose, mandibular hypoplasia, and corpus callosum hypoplasia.

\section{DISCUSSION}

SS is a rare disorder with autosomal recessive genetic transmission that is characterized by low birth weight, short stature, microcephaly, mental retardation, and atypical face appearance (beaklike nose, small forehead, micrognathia). There is no gender predilection and the incidence is 1/10.000. More than 60 SS cases have been described in the literature. In SS several anomalies related to central nervous system (CNS) have been described ${ }^{1-7}$. Arnold et al ${ }^{3}$ reported 3 cases with severe hydrocephalus. Howanietz et $\mathrm{al}^{4}$ detected enlarged cerebral ventricles in a 9-yearold patient with SS. Cherian ${ }^{5}$ detected marked dilatation in the right lateral ventricle in a patient with SS. Shanske et $\mathrm{al}^{1}$ demonstrated corpus callosum agenesis, cerebellar vermis agenesis, cerebral cortical dysplasia, and medial dorsal cyst with computed tomography in a patient with SS. Krishna et $\mathrm{al}^{6}$ detected a small cerebrum, a relatively large cerebellum, and a midline arachnoid cyst in a patient with SS. Sugio et $\mathrm{al}^{7}$ reported hypoplastic cerebrum and cerebellum in a 2-month-old male infant. The similarities in these publications suggest a common element of neuronal migration anomaly. Furthermore, Vincenzo et $\mathrm{al}^{8}$ described multiple intracranial aneurysms in a 17-year-old girl that presented with intracranial hemorrhage. Can et $\mathrm{al}^{9}$ reported the presence of lissencephaly and corpus callosum hypoplasia on cranial MRI in a 1-month-old newborn, as in our case.

In conclusion, we are of the opinion that in malformative syndromes such as SS, cranial MRI should be definitely performed to determine the correlations between the widespreadness and types of accompanying lesions, and to detect potential CNS anomalies.

\section{REFERENCES}

1. Shanske A, Caride DG, Menasse-Palmer L, Bogdanow A, Marion RW. Central nervous system anomalies in Seckel syndrome: report of a new family and review of the literature. Am $\mathbf{J}$ Med Genet. 1997; 70: 155-8.

2. Kutlu R, Alkan A, Kutlu O, Yakinci C. Seckel syndrome with polyarteritis nodosa. Indian Pediatr 2004; 41: 1158-61.

3. Arnold SR, Spicer D, Kouseff B et al. SeckelLike Syndrome in Three Siblings. Pediatr Dev Pathol. 1999; 2: 180-7. 
4. Howanietz H, Frisch H, Jedlicka-Kobler I, Stegar H. Seckel Dwarfism based on a Personal Observation. Klin Pediatr. 1989; 201: 139-41.

5. Cherian MP. Seckel-like syndrome or Seckel variants? Ann Saudi Med 2004; 24: 469-72.

6. Krishna AG, Scrimgeour EM, Zawawi TH. Seckel Syndrome in a Yemeni Family in Saudi Arabia. Am J Med Genet 1994; 51: 224-7.

7. Sugio Y, Tsukahara M, Kajii T. Two Japanese cases with microcephalic primordial dwarfism: classical Seckel syndrome and osteodysplastic primordial dwarfism type II. Jpn J Hum Gene Genet 1993; 38: 209-17.

8. D'Angelo VA, Ceddia AM, Zelante L, Florio FP. Multiple intracranial aneurysms in a patient with Seckel syndrome. Childs Nerv Syst. 1998; 14: $82-4$.

9. Can F, Ovalı Yılmaz G, Özkol M, Tarhan S. Seckel Sendromunda Görüntüleme Bulguları. Turkiye Klinikleri J Pediatr 2009;18: 328-31. 